\title{
THE LOGIC OF INSTITUTIONS IN A SYSTEMIC APPROACH. Institutions in Law and Law-related Fields as Closed and Open Systems
}

\begin{abstract}
I. A Logic of Systems
1. Both institutions and their components are conceptually represented as organised into some sorts of systems. This is the obvious outcome of the classificatory nature of the use of concepts and conceptual representations. ${ }^{1}$
\end{abstract}

At the same time, human practice often abuses conceptualisation. Namely, it often overgeneralises the reason why a choice is made in order to oversubstantiate a claim. To reach this oversubstantiation, it puts the claims into a more general context than is actually justified. ${ }^{2}$

Systems in operation, by and through which we live and continue our social practices, are contingent and casual in their basic character. Of course, this is not to say that the selection of their elements and the way of their organisation is a gratuitous action within an empty space, to be filled only by the wish and might of the day. For instance, there is some connection between their taking shape, on the one hand, and the factors that have been instrumental in shaping them, on the other - although the presence of these factors as well as their actual impact may be quite incidental from the point of view of the existence and, moreover, from the point of view of the emergence of those systems as systems.

The constitutional system of liberalism as historically established is, for instance, one of the several possible materialisations it could have had. It is one of the possible outcomes of human efforts through centuries to overcome contemporary misery by setting new framework for human action in its relationship to law and the state.

\footnotetext{
* Csaba Varga, Professor Emeritus, Philosophy of Law Institute of the Catholic University of Hungary \& Research Professor Emeritus, Institute for Legal Studies of the Hungarian Academy of Sciences. Чаба Варга, почесний професор, Інститут філософії права Католицького університету Угорщини, почесний професор-АосліАник, Інститут правових досліАжень Угорської акаАемії наук.

e-mail: varga.csaba@jak.ppke.hu

ORCID ID: https://orcid.org/0000-0001-5256-0518

${ }^{1}$ Csaba Varga, "Taxonomy of Law and Legal Mapping: Patterns and Limits of the Classification of Legal Systems,” Acta Juridica Hungarica, vol. 51, no. 4 (2010): 253-72, http://real-j.mtak.hu/765/1/ ACTAJURIDICA_51.pdf.

${ }^{2}$ Karl Marx and Friedrich Engels, The German Ideology, 3rd rev. ed. (Moscow: Progress, 1976).
} 
2. At all steps, there is a close interconnection between the shaping of ideas, on the one hand, and the available store of the modes of their implementation and reconsideration at any time, on the other. Even the contents, directions and limits of human imagination are a function of such an interaction. For in the total social process, each step and contributing component has a variety of meanings, faces and links and developmental alternatives, and only later will the effected events and connections decide which of them and in which a manner is to be actualised. Or, this is a multi-faceted and multi-directional process with several competitive chances; something that could only be broken down by a finalist reductionism (believing that an ultimate breaking down will be reached) in order to be traced back to a single, straightforward line of development.

In any case, to state that there has been some necessity in the course of actions to take shape and reach a conclusion is by far not to state that there has been a pre-existing universal idea that was to materialise in that way. Even the ontological reconstruction of the factors in play in the social conditioning of the course of events is a reconstruction of the road run by, and the links bridging, the individual chain of that course of events, and not a statement about the universal idea as having been necessarily materialised in the historically concrete realisation.

3. To be more precise: when speaking of systems of institutions and their conceptual representations, ${ }^{3}$ we have in mind at least four types, or levels, of these systems. Notably, (1) the actually existing concrete system, which is a unit that functions as it is (e.g., constitutional system of liberalism as practised in a given area in a given time, e.g., in the United States nowadays) (type 1); (2) the historically developed concrete system which is a unit that functions as it has been (e.g., constitutional system of liberalism as practised in a given area in a given period, e.g., in the United States since the time it developed) (type 2); (3) the generalisation of the historically concrete systems as developed in our civilisation (e.g., the constitutional system of liberalism as known and practised in our civilisation) (type 3); and (4), the core idea of the functioning underlying all kinds of generalisation (e.g., the abstract universal formulation of the ultimate principles of operation, of which the constitutional system of liberalism is but one of the theoretically possible forms of realisation) (type 4). As to the origins of such an abstract and universal formulation, it may be either gained by theoretical reconstruction or formulated as a preconceived idea, in order to offer a basis for deducing justification of the historical realisation(s) from them.

As can be seen, types 3 and 4 are not units functioning as they are or have been. Type 4 is an idea (1) in which "laws" (i.e., effects, interconnections) of functioning may be observed in abstract generality on ideal conditions. Type 3 is one of the former's applications to, or materialisation under, historically particular conditions.

\footnotetext{
${ }^{3}$ In a most general sense, cf. N. Emrah Aydinonat and Petri Ylikoski, "Three Conceptions of a Theory of Institutions,” Philosophy of the Social Sciences, vol. 48, no. 6 (2018): 550-68, https://doi.org/ $10.1177 / 0048393118798619$.
} 
4. All systems, ideas and realisations form an endless continuum. Types 1 to 4 are nothing but meaningfully definable stages of this continuum, and by far not its limiting points. This is the reason why almost all of them may display almost all the properties that can characterise them at all.

\begin{tabular}{|c|c|c|}
\hline abstractness & ideal & $\begin{array}{l}\text { internal coherence } \\
\text { and consequentiality }\end{array}$ \\
\hline ideal type & $\begin{array}{c}\text { ideal of functioning } \\
\text { [type 4] }\end{array}$ & \\
\hline empirical types & $\begin{array}{l}\text { historically particular formulation } \\
\text { of the ideal of functioning } \\
\text { [type 3] } \\
\text { historically particular generalisation } \\
\text { of the developmentally defined sets } \\
\text { of concrete actual functioning } \\
\text { [type 2] } \\
\text { concrete actual functioning } \\
\text { [type 1] }\end{array}$ & historical types \\
\hline concreteness & real & contingency \\
\hline
\end{tabular}

Abstractness, internal coherence and consequentiality, as well as ideality, are decreasingly, while concreteness and contingency, as well as reality, are increasingly present in the line between the ideal and the actual functioning.

At the same time and to a decreasing degree, types 1,2 and 3 are historical ones; and types 1 and 2 are concomitantly empirical ones as well. Obviously, it goes without saying that there would be no sense in projecting any ideal of functioning into a vacuum with no empirical background whatsoever. Consequently, at the same time, even empirical types may be used as ideal ones. And, obviously again, neither abstractness nor concreteness have end-points. For the question of whether I can define types more abstract or more concrete than they actually are is one of expediency in the determination of the levels of analysis.

5. Historically, only types 1, 2 and 3 do exist, representing historically characteristic typical configurations. They are at the same time needed for theoretical description, as they hold the name of what is to be conceptualised as existing. Ontologically, the existence of each of them can be established. Albeit type 4 claims to be over and beyond history, the social existence of the ideal representation it embodies can also be delimited historically. 
6. Human action is by definition teleological. Telos [ $\tau \dot{\varepsilon} \lambda \circ \varsigma]$ as a model is at all times working in it in order to direct it. ${ }^{4}$ It however does not turn practice into mere implementation. The ideal remains ideal, the practical practical. Both the motive force and the criterion of practice are what is considered practical. Of course, consideration of what is practical may also set the implementation of something ideal as target. But motive force and criterion remain unchangedly what is considered practical. Attributes of ideal, no matter of what kind and weight they are, can only exert an influence when filtered through the consideration of what is practical.

\section{Ideal Types and Historically Concrete Manifestations}

7. A notional distinction among the levels of systems, ideas and formulations is a methodological requirement. Since to differing levels and corresponding concepts often the same label is assigned, it is not exceptional that they are treated in an undifferentiatedly unifying way, which is a common cause of confusion.

For instance, as to the doctrine of the division of powers, ${ }^{5}$ the only realistic references are those historical manifestations which are commonly characterised as realisations more or less distorted or imperfect (type 1). Those imperfect realisations are seen as variations of a historical descriptive type (type 2) which is in turn the implementation of a historical ideal type (type 3). In such a way, all practical measures taken in a historically concrete situation are in the final analysis traced back to a broad, well-defined socio-historical context which, in this case, includes an immense variety of things, from the fight for constitutionalism in England, via the way in which Montesquieu was to overcome absolutism in France by (mis)interpreting English constitutionalism, to the achievement of the fathers founding the Constitution in the United States, including the way in which they (mis) understood both England, Montesquieu and their own perspectives, and also including the (mis)understanding, by all historical actors, of the richness of the store of means available in principle. But is it really so that the idea (1) of functioning underlying the doctrine of the division of powers gets reduced to it? Obviously, without universalising the actually particular, in theory I cannot say "yes" to this question. If I still do so, which occurs too often in practice, it implies that I have opted also for some methodological consequences. Let us see three of them.

7.1. Universalisation can only be done through assuming notional dichotomies between complementary concepts, $C$ and non- $C$, which, albeit antagonistic to one another, wholly cover the field. Thereby I erect an artificially rigid two-poled scheme, only to exclude dialectics and historical sensitivity.

\footnotetext{
${ }^{4}$ Colin Allen and Jacob Neal, "Teleological Notions in Biology”, in The Stanford Encyclopedia of Philosophy, ed. Edward N. Zalta, https://plato.stanford.edu/archives/spr2020/entries/teleology-biology/.

${ }^{5}$ Jean Jacques Granpré Molière, La théorie de la constitution anglaise (Leyde: Presse Universitaire, 1972); W. B. Gwyn, The Meaning of the Separation of Powers: An Analysis of the Doctrine from Its Origin to the Adoption of the United States Constitution (New Orleans: Tulane University, 1965).
} 
For instance, it is a rather general pattern for contemporary political philosophies to regard the "Third Way"-type searches of a way out from continued crises in Europe in general and in its Central and Eastern part in particular, ${ }^{6}$ as by-products themselves of the same crises, fallen into irrationality. Well, this critique latently includes an assumption of capitalism and socialism, offering in their historically developed forms the only potentialities of the paradigm "capitalism/socialism" and, thereby, also exclusive alternatives. Consequently, the universalistic assumption in work here excludes questions like "Is it this and only this that is capitalism/socialism?" "Is there indeed no choice in between these poor kinds of representation?" "And no choice beyond them either?"

7.2. As to the second consequence, my approach will be prejudiced from the very beginning if I can only count with the individual features of a concrete historical manifestation (type 1) as distortions of some underlying principle(s). If it is the case, it assumes the existence of something of which they are nothing but the individual realisation. Well, this is also an assumption justifiable only by a finalist approach.

7.3. Finally, universalisation of the particular dispenses with the search for identifying last principles (type 4). If there are no ultimate principles, then what remains can only reflect historical types upon one another, which has very limited profit, not transcending even the level of historiography. In contrast, theory starts by reconstructing the basic function (type 4) which makes it already possible to approach the historically particular formulation (type 3) as an intermediary concretisation.

For instance, the classical doctrine of the division of powers is not an empirical theory of development. Montesquieu never claimed that power came to being at any place or time as divided in a tripartite way. He simply contrasted a positive utopia to the negative one he had already had. ${ }^{7}$ Notwithstanding this, his positive utopia is usually treated as a final formulation touching upon the topic. If it is so, no theory based on the concentration of powers should ever be reconcilable with his doctrine of the division of powers.

Well, the Bolshevik theory of the state ${ }^{8}$ has since long professed to be antagonistic to western democratic traditions. But ideological claims, e.g. for complete disruptcy and discontinuity, are not to be taken as a substitute to theoretical analysis. In order to assess what the whole dispute is about, even a historical reference may be revealing. In fact, Bolshevik theory was launched as a revolutionary program of why and how to seize power, and the Bolshevik criticism of Montesquieu theorised about power at a time when it was at the threshold of actually seizing it. In response to that confrontation, it too misinterpreted

\footnotetext{
${ }^{6}$ Steve Bastow, Third Way Discourse: European Ideologies in the Twentieth Century (Edinburgh: Edinburgh University Press, 2003).

${ }^{7}$ Simone Goyard-Fabre, Montesquieu: La nature, les lois, la liberté (Paris: Presses Universitaires de France, 1993).

${ }^{8}$ Csaba Varga, "Lenin and the Law: A Case-study on the Borders of Legal Normality," Central European Political Science Review, vol. 20, no. 75 (2019): 131-79.
} 
Montesquieu, not to recognise anything from his teaching but an antirevolutionary program of resigning, once and for all, of the seizure of power.

Or, in sum, all this means that both adherents and critics have instrumentalised Montesquieu's positive utopia by transforming his statements into ideology. Western tradition has developed universalised terms which can however be valid in their proper context only, as opposed to the Russian revolutionaries who have narrowed them only to mean the negation of their very dreams.

The genuine problem is that, in fact, none of them has realised that what they actually did was to intermingle different levels of analysis, and this is the reason they had to become mutually antagonistic. To be sure, none of them stated something different on the same subject, but they launched differing statements on differing subjects.

At the same time, it is to be noted that a doctrine of "division of labour" in the power machinery was finally developed by the Bolsheviks, pushed to offer (no matter how much imperfect, but, after all, a kind of ) an alternative to the Western conception of the division of powers. ${ }^{9}$ Presumably, the ensuing principle of the unity of powers with only a hazy and weak "division of labour" within it will remain in force so long as the one-party-rule can impose itself upon society. On the other hand, even a system of "division of labour" in the power machinery can develop further with some - even if rather limited - potentialities.

As to the relationship of these conflicting approaches, mutual exculpation qualifies itself as bare ideology. Theoretically both are levelled at type 3.

\section{Ideal Type as a Normative Ideology}

8. All the systems, conceptual representations and operations we have surveyed thus far are of a descriptive character and function, called into being as instruments to grasp conceptually what institutionally exists. In short, they qualify as theoretical representations.

As is known, theoretical activity is a specific terrain of homogenising human activities, distinguished from both other domains of a homogenising effect (e.g. custom, convention, such as speech, law, politics), on the one hand, and the vast field of the heterogeneity of everyday life, on the other. Still, it does not require that the various forms of objectification in one area cannot be made use of in other areas as well. Ontological investigation suggests that all kinds of ideal representation and objectification - no matter whether they are of a theoretical or practical character - can turn into ideology. All this can be done by putting them into another context and making use of them specifically.

This is to say that (1) everything theoretical can be made a factor of practical action by putting it into a practical context; and (2) everything in a given homogeneous field can be taken out from it and either lifted in another homogeneous field (e.g. the linguistic,

\footnotetext{
${ }^{9}$ Csaba Varga, "La séparation des pouvoirs: idéologie et utopie dans la pensée politique," Acta Juridica Academiae Scientiarum Hungariae, vol. XXVII, no. 1-2 (1985): 243-50.
} 
semantic or rhetorical aspects of law, or the law's political use) or merged into the heterogeneity of everyday life (e.g. the uses of social conventions, language, law or politics in a way annihilating their particularities) - well, in both cases with prior determinations suspended in order to let them act as adapted to their new environment.

9. Being adapted to new environment is a change of memberships of the systems concerned. In case of conceptual representations, a positive value-judgement and/or a deontic operator attached to them can effect this change. For a theoretical statement becoming a standard for practical action is already an ideological use. It involves its transformation into normative ideology.

10. Systems may be used as normative patterns in three situations: (1) in case of conflict with the systems' idea in question, to modify the underlying system in the given direction; (2) in case of an internal contradiction within the underlying system, to resolve it in the given direction; and (3) with no external or internal conflict provided, to prescribe it the change as needed or to define the direction and substance of its further development when needed.

11. One of the fields for normative ideologies to provoke change by defining who is to act, when, on what, why and how is the so-called filling of gaps. As is known, "gap" is a normative concept, being the function of a normative framework (a) to qualify any situation (position, etc.) within the system as a gap; in order (b) to fill it (c) in a given way, (d) with a substance taken from within the system by the effect that (e) at least ideologically, the filling of the gaps does not implement any genuine modification in the system, although it strengthens its individual position within and as a member of the system, as made to be more conforming to the system.

Filling the gaps is one of the most important factors to enhance the practicability of the systems, as it makes it possible to them to preserve their identity while making them keep in pace with time. Or, there have always been two basic means of sublated innovation in institutions: transplantation (i.e., injecting something not known in the system which is said to have been known within the underlying system) and fiction (i.e., claiming that what is in point of fact new in the system is nothing else but the implicit extension as made in the system). ${ }^{10}$

(In the field of law, it seems to be a commonplace that in addition to fiction proper, as the earliest and most common and lasting instrument to provoke and, at the same time, veil change, almost ninety-five percent of the four thousand years of recorded legal history was dominated by innovative legislation, ideologically embellished as bare restitution of what the "good old custom" of the country had been, in usage already in Hammurabi's Prologue to his Law Book and surviving till the enacting clauses of the last French king.)

\footnotetext{
${ }^{10}$ Csaba Varga, "Is Law A System of Enactments?” In Theory of Legal Science, ed. Peczenik, Aleksander, Lars Lindahl, and Bert van Roermund, 175-82 (Dordrecht-Boston-Lancaster: Reidel, 1984), https:// doi.org/10.1007/978-94-009-6481-5_14.
} 
And the reason for its success is easy to see: it has been a conveniently flexible means, suited to meet two basic requirements contradicting one another, that is, to effect change as needed (i.e., to function as re-adapted to the changing needs) while preserving the system's identity (i.e., to reproduce its basic continuity over all the series of actual discontinuities) within an apparent harmony.

12. In principle, each and every one of types 1 to 4 can be used as normative ideology if reflected onto all other ones of the same types. Even the conceptual representation of the concrete actual functioning (type 1) can be made a normative ideology by reflecting it on the conceptual representation of its posterior functioning.

(Taking into consideration the open texture of concepts and the inherent fuzziness of argumentation, we have to realise that there is a large room for transcendence both among the undifferentiated concepts we use and among the undifferentiated systems we refer to. To avoid transcendence is a question of the formulation of premises, an operation that has nothing to do with reflection of one concept onto another in their normative usage.)

13. The normative use of ideal systems and conceptual representations is the explanation of the fact why and how these systems and representations can be or turn to be of use in or turn to be a decisive factor of social processes even if for long a period they could at most be qualified as empty classes. Because they are normative, expectations about them do not disqualify them, even if not met with success. Or, what is more, even dead systems and representations can finally exert a decisive influence to overcome the inertia and to push a process forward or turn it backwards.

For instance, in Hungary, the wish for implementing the Soviet-patterned Constitution of 1949 into practice seemed for long an aborted idea from the very beginning. Four decades ago, during the 1980s, the ever growing gap between words and facts induced some constitutionalists to demand realism instead of illusionism, i.e., the adaptation of its wording to prevailing practice, to the hard fact of one-party-rule, i.e., of the hegemonist (and practically singly ruling) Communist Party. Luckily enough, this proposal failed by the fear that thereby the only thing that remained, that is, the bare possibility of fighting for more or truer parliamentarism through referring to a text enacted by the communists themselves, would also be lost.

\section{Objectivity and Contingency of Systems}

14. For a given historical actor in a concrete situation an immense amount of social objectivations, conventions, institutions, etc. are given. They form to him what we call tradition. All the components of tradition serve to him as an objectively given framework, in respect to which he may have only alternatives of following it or departing from it, but in any case he will not be in a position to dispose of it freely.

Escaping from social bounds contradicts the very notion of social activity; and, paradoxically, in modern society even the first attempt at escaping is itself only conceivable 
through conventionalised social practices. ${ }^{11}$ In short, socialisation, i.e., a very specific learning process, is the only available pattern for the individual in his relationship to social totality in modern society.

At the same time, the individual is certainly not in isolation but is a component part of the social totality. What seems to be objectively given to him in individual situations has in fact no existence of its own, independent of the total set of individual social practices in the same totality. What social tradition is, is in the last analysis a function of the total sum of social practices, reproducing the tradition through practising it. Consequently, reproduction of a tradition is a continued learning process, in which taking its cognisance will amount to re-adapting it, and its interpretation to reinterpreting it as part of social practices. In other words, every human act establishing what we call homogeneous can only be performed within the boundaries (and upon the basis and for the sake) of (and, in the final resort, as subordinated to) what we call the heterogeneous. In the same way: every human consideration to what we call epistemic can only take place within the boundaries (on the basis and for the sake) of (and, in the final resort, as subordinated to) what we call ontic.

15. In the light of an ontological description, the search for a practical solution is nolens volens a model-patterned reaction to a given situation - independently of the agent's subjective intention. At the same time, also independently of any intention, that which is to come objectively out of this will be something more or less, or, in any case, other, than what the original intention was. It will necessarily be a practical answer to a practical challenge as it was sensed and interpreted by the acting agent. Thus, it will necessarily be an imprint of all of the moments that have been present in the situation, contingent from the point of view of the social totality.

There is a particular dialectic at play here. For the reaction, no matter to what extent and how intentionally it is model-patterned, it will be the issue of practical considerations in a practical context. Even what is manifested as non-practical is made so by practical consideration. And this applies to everything. Anything claimed to be eternal is a function of practical interest to project it as fetishised. It is ideology that is at work in such and other cases of overgeneralised interests.

To qualify a statement as ideology is an ontological statement upon actual use, and not a judgement upon foundation or value. As is known, ideology is a form of consciousness called into being to influence practical human (re)action. In contrast, theory is a form of consciousness called into being to reconstruct the interconnections of any process, including its ideology.

16. The theoretical reconstruction I have in mind can be nothing but ontological. For the resultant epistemological reconstruction arrived at may at most be a negative one,

\footnotetext{
${ }^{11}$ Eerik Lagerspetz, A Conventionalist Theory of Institutions (Helsinki: The Philosophical Society of Finland, 1989); Eerik Lagerspetz, The Opposite Mirrors: An Essay on the Conventionalist Theory of Institutions (Dordrecht and Boston: Kluwer, 1995).
} 
demonstrating, e.g., the false conclusion reached by false inference from false premises - i.e., its own incompetence for thorough reconstruction. It is only ontological reconstruction that can answer why the relevancy of epistemology is limited, why it is so that forms of false consciousness can be instrumental, and even socially needed on occasion.

It is only ontological reconstruction that can offer an explanation of the paradox of interpretation amounting to reinterpretation or misinterpretation, and of reproduction amounting to production or misproduction.

17. Systems are located in a continuum of a constant motion and change. It is a continuum in light of both their hierarchical structuralisation and their self-reproduction in a continued process in social totality.

To be more precise, to exist as placed in a continuum may have two senses. Ontologically, it is a form of existence through constant self-reproduction in an endless series of reinterpretations. (Reinterpretation here is an ontic sequence of purposeful practical reactions, and not a critical attitude, which is epistemic.) Epistemologically, it denotes an ideal existence necessarily having fuzzy conceptual boundaries.

These features are common to objects of social ontology. ${ }^{12}$ Nevertheless, I wish to emphasise the considerable extent to which the links are epistemologically loose among sequences in both the systems' lines of development and their hierarchic structures. The systems in question are historically developed sets in which all may have had alternatives to those actually established (although they do not). It is most plausible to realise it in limiting cases at both the micro- (type 1) and macro- (type 4) level.

As, for instance, to the micro-level, each concrete, actually functioning system of constitutional liberalism bears the imprint of the place and time of its formation, i.e., characteristics that are explainable in the context of their actual shaping. As to the macro-level, the connection of ideality and actuality is only explainable exclusively by their development. Let us assume that I should have to invent the constitutional system of liberalism now. As a matter of fact, I can by no means take it for granted that I would lay its foundations by the same philosophical, anthropological, etc. assumptions as it was done several centuries ago. And the same holds true vice versa. I cannot be sure that any concrete system of constitutional liberalism that has ever existed could be inferred from or justified by the assumptions suggested by human inventiveness now. And we have to add that theoretical variations are, in contrast to actual occurrences, practically endless.

The same loose contacts can be characteristic also of actual operating systems. Theoretical reflection often groups systems of autonomous development (e.g. ones in England or in the United States) together; the past of which may count more in centuries

\footnotetext{
${ }^{12}$ György [George] Lukács, A társadalmi lét ontológiájáról [Zur Ontologie des gesellschaftlichen Seins]. Vol. I-III (Budapest: Magvetö, 1976); Csaba Varga, "From the Ontology of Social Being to the Law's Ontology," Journal of the Siberian Federal University: Humanities and Social Sciences, vol. 8, no. 10 (2015): 2002-17, http://elib.sfu-kras.ru/bitstream/2311/19820/4/01_Varga.pdf.
} 
than others - due to recent transplantation or imposition (e.g. in the Federal Republic of Germany or Japan) - may count in decades.

It is precisely due to these features that they turn into genuinely historical phenomena, both marking and being made by history. For otherwise, if they were units unchangedly identical with themselves, their history could only be quasi-history at most, with mere alternation of blocks in a mechanical world, made up of discrete motions of discrete elements. To put it another way: the continuum the systems embody is the outcome of their dialectic character. Their dialectic is one of sublation, that is, of unceasing preservation and change.

18. It is also their existence as a continuum that makes it possible to understand why their historical nature is so important from the point of view of practical action as well. For their being a continuum in constant motion and change is also a function of their environment, in the interaction with which they are shaped. Or, the way they transcend themselves and by which their reproduction through their continued reinterpretation is achieved is not only a function of them but of the general culture and (political, legal, etc.) cultures of specialised fields as well. It is so to such an extent that even the fight for them may have alternative actions to take. Namely, an action directed at them may aim at their shaping in a direct way (as, in the case of law, directed at its enacted text), as well as in an indirect way, through the cultural context in the interaction with which they are shaped (as, in the case of law, with the mediation of legal policies and legal culture, made to be strong enough to be able to have a genuine role to play).

\section{Limits and Bonds, Consequentiality and Practicability of a System}

19. The question of what properties, features and traits a system may develop or take over by transplantation from another system is quite open, having no restriction from the point of view of social totality. ${ }^{13}$ It is not even a system-related question; it can only be raised as a question of the limits of law, politics, etc. in a final resort by ontology: what can be practicable, i.e., fulfilling a genuine function, in a social system?

On the level of abstract generality, the answer is rather vague. For, in point of principle, there is no limit predetermining what can turn into instrumental or practicable in a social context as anything whatsoever can do so.

It means that the possibility of systems coming into being as mixed is, so to speak, endless. One could even state that only mixed systems are practicable in practice, or that non-mixed systems are, without exception, issues of theoretical reduction.

20. Is there any precondition to the point that systems are identifiable as such just because they have some definite elements organised into a system? The question is directed at their own determination from within. Or, is there any limit set by the systems, defining

\footnotetext{
${ }^{13}$ Csaba Varga, "Transfer of Institutional Patterns: World Bank, Ethno-centrism, and New Challeges: A Case-study in Law," Central European Political Science Review, vol. 13, no. 48 (2012): 25-60.
} 
their own identity by minimum contents as necessary and sufficient conditions for their existence? Or, is there any self-imposing limit of the system which might of course be ignored, but only with the consequence of placing itself out of the system?

This is a topical issue, with enriching debates in the Western hemisphere focusing upon them. Only to mention a few: expropriation versus privatisation; planning versus invisible hand; leftism versus rightism in the same system, etc. Moreover, not long ago this was the key issue of the crises of the so-called "existing socialisms" as well. Only to name a few: economic reform and rigidified Stalinist superstructure; bankruptcies of sham liberalisation; the one-party's crave for legitimacy without offering anything in return for legitimation, etc. And the case of Hungary was a novel proof for the hard bonds of a system. For economists claimed then that partial reform, softened and extended over time with no breakthrough in the political field, meant planning failure taken for granted; and again, they were right. Then the dilemma went on to be hardened: was the tabooing of party-rule by one party simply setting framework for a reform, or was it a touchstone of the left for attempting to reform from within, too much well-deserved?

21. To learn that, defying human imagination, the systems mankind has established are only storehouses of contradictions yet they still function well - this realisation is a shocking experience for the human mind to accept. But to expect that systems have developed with maximum cohesion, consequentiality and freedom from contradictions is a mere theoretical requirement, reflecting more the subject than the object, which, due to the logical ideal of thinking, is limited in imagination. And theory reflects, in addition to the external world, its own homogenising principles, too.

In fact, systems function according to their own homogenities, which are far from the ideal of logic. As practical systems, they are to cope with practical problems resulting in compromise solutions to the detriment of the principles of cohesion, consequentiality and coherence, that is, to the detriment of logic. This is the reason why there is always some kind of discrepancy between any formalized criteria and their practical satisfaction in their implementation, which is emphatically characteristic of the world of law. ${ }^{14}$

At the same time, contradictoriness with tensions in functioning is a basic fact of ontology. Instead of standing for the temporariness and deficiency of anything humane after the first sin has been committed with the actors ousted, it stands for a character present everywhere and at every time, a character that may grow to be a burden but, in

\footnotetext{
${ }^{14}$ Cf. two approaches to it, Atiyah-Summers (P. S. Atiyah and R. S. Summers, Form and Substance in Anglo-American Law: A Comparative Study of Legal Reasoning, Legal Theory, and Legal Institutions (Oxford: Clarendon Press, 1991)), on the one hand, and MacCormick-Weinberger (Neil MacCormick and Ota Weinberger, An Institutional Theory of Law: New Approaches to Legal Positivism (Dordrecht, etc.: D. Reidel Publishing Company, 1986)), Weinberger (Ota Weinberger, Law, Institution and Legal Politics: Fundamental Problems of Legal Theory and Social Philosophy (Dordrecht: Kluwer Academic Publishers, 1991)), MacCormick (Neil MacCormick, Institutions of Law: An Essay in Legal Theory (Oxford: Oxford University Press, 2007)), on the other.
} 
most cases of balanced development, serves rather as one of the most powerful reserves for the internal renewal of the system. Internal renewal is a way of making optimal use of the systems' own potentialities, in order to allow it to keep pace (through its continuous re-adaptation through continued re-adjustments) with overall development. This is the reason why systems process outer conflicts into inner ones by forwarding competitive arguments to solve them. This is the reason why systems develop conflicts through series of temporary solutions, stand-still being just a name for the theoretical division line between situations of conflicts in succession of one another.

(C) C. Varga, 2020

\section{Bibliography}

Allen, Colin, and Jacob Neal. "Teleological Notions in Biology." In The Stanford Encyclopedia of Philosophy, edited by Edward N. Zalta. https://plato.stanford.edu/archives/spr2020/entries/ teleology-biology/.

Atiyah, P. S., and R. S. Summers. Form and Substance in Anglo-American Law: A Comparative Study of Legal Reasoning, Legal Theory, and Legal Institutions. Oxford: Clarendon Press, 1991.

Aydinonat, N. Emrah, and Petri Ylikoski. "Three Conceptions of a Theory of Institutions." Philosophy of the Social Sciences, vol. 48, no. 6 (2018):550-68, https://doi.org/10.1177/0048393118798619.

Bastow, Steve. Third Way Discourse: European Ideologies in the Twentieth Century. Edinburgh: Edinburgh University Press, 2003.

Goyard-Fabre, Simone. Montesquieu: La nature, les lois, la liberté. Paris: Presses Universitaires de France, 1993.

Granpré Molière, Jean Jacques. La théorie de la constitution anglaise. Leyde: Presse Universitaire, 1972. Gwyn, W. B. The Meaning of the Separation of Powers: An Analysis of the Doctrine from Its Origin to the Adoption of the United States Constitution. New Orleans: Tulane University, 1965.

Lagerspetz, Eerik. A Conventionalist Theory of Institutions. Helsinki: The Philosophical Society of Finland, 1989.

Lagerspetz, Eerik. The Opposite Mirrors: An Essay on the Conventionalist Theory of Institutions. Dordrecht and Boston: Kluwer, 1995.

Lukács, György [George]. A társadalmi lét ontológiájáról [Zur Ontologie des gesellschaftlichen Seins]. Vol. I-III. Budapest: Magvető, 1976.

MacCormick, Neil, and Ota Weinberger. An Institutional Theory of Law: New Approaches to Legal Positivism. Dordrecht, etc.: D. Reidel Publishing Company, 1986.

MacCormick, Neil. Institutions of Law: An Essay in Legal Theory. Oxford: Oxford University Press, 2007. Marx, Karl, and Friedrich Engels. The German Ideology, 3rd rev. ed. Moscow: Progress, 1976.

Varga, Csaba. "Is Law A System of Enactments?" In Theory of Legal Science, edited by Peczenik, Aleksander, Lars Lindahl, and Bert van Roermund, 175-82. Dordrecht-Boston-Lancaster: Reidel, 1984. https://doi.org/10.1007/978-94-009-6481-5_14.

Varga, Csaba. "La séparation des pouvoirs: idéologie et utopie dans la pensée politique." Acta Juridica Academiae Scientiarum Hungariae, vol. XXVII, no. 1-2 (1985): 243-50. 
Varga, Csaba. "Taxonomy of Law and Legal Mapping: Patterns and Limits of the Classification of Legal Systems." Acta Juridica Hungarica, vol. 51, no. 4 (2010): 253-72. http://real-j.mtak.hu/765/1/ ACTAJURIDICA_51.pdf.

Varga, Csaba. "Transfer of Institutional Patterns: World Bank, Ethno-centrism, and New Challeges: A Case-study in Law." Central European Political Science Review, vol. 13, no. 48 (2012): 25-60.

Varga, Csaba. "From the Ontology of Social Being to the Law's Ontology." Journal of the Siberian Federal University: Humanities and Social Sciences, vol. 8, no. 10 (2015): 2002-17. http://elib.sfu-kras.ru/ bitstream/2311/19820/4/01_Varga.pdf.

Varga, Csaba. "Presumption and Fiction, Or the Gist of Legal Technicalities." Pázmány Law Review, vol. VI (2018): 105-30. https://jak.ppke.hu/uploads/articles/311739/file/PLR_6_2018.pdf.

Varga, Csaba. "Lenin and the Law: A Case-study on the Borders of Legal Normality." Central European Political Science Review, vol. 20, no. 75 (2019): 131-79.

Weinberger, Ota. Law, Institution and Legal Politics: Fundamental Problems of Legal Theory and Social Philosophy. Dordrecht: Kluwer Academic Publishers, 1991.

Чаба Варга. Аогіка інститутів у системному піАході. Інститути в праві та пов'язаних із правом царинах як закриті та віАкриті системи

Анотація. Що стосується концептуалізації будь-якого інституту, то очевиАно, що оАин і той самий умовний термін може охоплювати чотири типи інституціональних систем: (1) фактично існуюча конкретна система, яка є одиницею, що функціонує як вона $є$ (наприклаА, конституційна система мібералізму як така, що ії практикують на певній території в певний час, як у Сполучених Штатах сьогоАні); (2) історично розроблена конкретна система, яка $\epsilon$ одиницею, що функціонує так, як вона була (наприклаА, конституційна система мібералізму, що ії практикують на певній території в певний періоА, як у США, з моменту виникнення); (3) узагальнення історично конкретних систем, що склалися в нашій цивікізації (наприклаА, конституційна система Аібералізму як така, що ії знають і практикують у нашій цивілізації); (4) основна ідея функціонування, що межить в основі всіх видів узагальнення (наприклаА, абстрактне універсальне формулювання остаточних принципів Аії, Аля яких конституційна

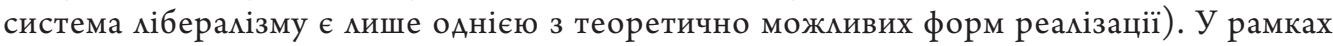
квазімонографічного аналізу трактується роль цих інституціональних систем як нормативної ідеології, а також їх фактична об’єктивність і непередбачуваність.

КАючові слова: інститути в праві; інституціональні системи; системний піАхіА; закриті та віАкриті системи; конституційна система Аібералізму.

\section{Чаба Варга. Аогика институтов в системном подходе. Институты в праве и связанных с правом областях как закрытые и открытые системы}

Аннотация. Что касается концептуализации мюбого института, то очевиАно, что один и тот же условный термин может включать четыре типа институциональных систем: (1) фактически существующая конкретная система, которая является еАиницей, функционирующий как она есть (например, конституционная система миберализма как таковая, которую практикуют на определенной территории в определенное время, как в Соединенных Штатах сегоАня); (2) исторически разработанная конкретная система, которая является единицей, функционирующей так, как она была (например, конституционная система миберализма, которую 
практикуют на определенной территории в определенный периоА, как в США, с момента возникновения); (3) обобщение исторически конкретных систем, сложившихся в нашей цивилизации (например, конституционная система миберализма как такая, которую знают и практикуют в нашей цивилизации); (4) основная идея функционирования, лежащая в основе всех видов обобщения (например, абстрактная универсальная формулировка окончательных принципов Аействия, Аля которых конституционная система миберализма явмяется мишь оАной из теоретически возможных форм реализации). В рамках квазимонографичного анализа трактуется роль этих институциональных систем как нормативной идеологии, а также их фактическая объективность и непреАсказуемость.

Ключевые слова: институты в праве; институциональные системы; системный подход; закрытые и открытые системы; конституционная система миберализма.

Csaba Varga. The Logic of Institutions in a Systemic Approach. Institutions in Law and Law-related Fields as Closed and Open Systems

Abstract. As to the conceptualisation of any one institution, the apparently identical notional term can cover four types of institutional systems: (1) the actually existing concrete system, which is a unit that functions as it is (e.g., constitutional system of liberalism as practised in a given area in a given time, e.g., in the United States nowadays); (2) the historically developed concrete system which is a unit that functions as it has been (e.g., constitutional system of liberalism as practised in a given area in a given period, e.g., in the United States since the time it developed); (3) the generalisation of the historically concrete systems as developed in our civilisation (e.g., the constitutional system of liberalism as known and practised in our civilisation); (4) the core idea of the functioning underlying all kinds of generalisation (e.g., the abstract universal formulation of the ultimate principles of operation, of which the constitutional system of liberalism is but one of the theoretically possible forms of realisation). Within a quasi monographic analysis of them, both their role as a normative ideology and their actual objectivity and contingency are treated.

Keywords: institutions; institutional systems; systemic approach; closed and open systems; constitutional system of liberalism.

ОАержано/Received 15.11.2020 